\title{
ÉVOLUTION DES CARACTÉRISTIQUES PHYSICO-CHIMIQUES DE LA VIANDE DE PORC AU COURS D'UNE CONSERVATION DE 20 MOIS A -20 oC
}

\author{
R. GOUTEFONGEA et C. VALIN \\ Station de Recherches sur la Viande, \\ Centre de Recherches de Clermont-Ferrand, I. N. R. A., \\ 63 - Saint-Genès-Champanelle
}

\section{RÉSUMÉ}

La congélation de la viande de porc à $-20^{\circ} \mathrm{C}$, en sacs étanches, et sous vide partiel, et sa conservation à la même température pendant une durée de 20 mois, permettent les observations suivantes :

- La perte par exsudation croît régulièrement avec la durée de conservation pour atteindre 5,7 p. Ioo au bout de 20 mois.

- L'eau " liée " aux protéines marque une baisse au cours des 4 premiers mois de conservation, puis reste constante.

- Il n'y a pas de dénaturation importante des protéines au cours de la conservation.

- L'apparition des produits de dégradation $\left(\mathrm{NH}_{3}\right.$, nucléotides déphosphorylés) est très lente. Les teneurs de la viande en ces produits sont analogues, au bout de 20 mois de stockage, à celles observées dans la viande fraîche conservée 8 jours à $+4^{\circ} \mathrm{C}$. 20 mois.

- L'oxydation des lipides reste très faible et seule une légère lipolyse apparaît au bout de

- Malgré une augmentation nette, après I an, des activités hydrolytiques libres après décongélation, on ne note pas d'évolution sensible de ces viandes conservées $4^{8} \mathrm{~h}$ à $+4^{\circ} \mathrm{C}$ après décongélation.

Dans nos conditions expérimentales, la congélation de la viande de porc peut être prolongée sans inconvénient au-delà de la limite habituellement admise, qui est de 6 mois à $-18{ }^{\circ} \mathrm{C}$.

\section{SUMMARY}

\section{EVOLUTION OF THE PHYSICO-CHEMICAL CHARACTERISTICS}

OF PIG MEAT PRESERVED AT $-20^{\circ} \mathrm{C}$ DURING 20 MON'THS

The following observations may be made on pig meat frozen at $-20^{\circ} \mathrm{C}$ in tight bags under partial vacuum and preserved at the same temperature during 20 months :

- The loss due to exsudation regularly increases when the preservation lasts longer and attains 5.7 p. Ioo after 20 months.

- The amount of water "bound " to the proteins decreases during the first 4 months of preservation and then remains constant. 
- There is no important denaturation of the proteins during the preservation.

- The appearance of degradation products $\left(\mathrm{NH}_{3}\right.$, dephosphorylated nucleotides $)$ is very slow, and the amounts contained in the meat after 20 months of storage are analogous to those observed in the fresh meat preserved 8 days at $+4^{\circ} \mathrm{C}$. months.

- The oxydation of lipids remains very low and only a slight lipolysis appears after 20

- In spite of a definite increase of the free hydrolytic ac'ivities when the meat is thawed after I year, no sensible evolution has been noticed in these meats preserved $4^{8}$ hours at $+4^{\circ} \mathrm{C}$ after thawing.

Under our experimental conditions, deep freezing of $\mathrm{pi}_{\text {is }}$ meat can be prolonged beyond the usually admitted limit, i. e. 6 months at - I 8 ० 